\title{
A Mediating Role of Job Security between Trust and Employees' Performance: A Case of Private Sector Hospitals of Hazara Division, Pakistan
}

\author{
Waqar Ahmed ${ }^{1}$, Assistat Professor Dr. Muhammad Yasir ${ }^{2}$ \\ Rashed Nawaz ${ }^{3}$, Imran $^{4}$, Akhtar Nawaz \\ ${ }^{1}$ Research Scholar, Department of Management Sciences, Hazara University Mansehra \\ ${ }^{2}$ Head of Department of Management Sciences, Hazara University Mansehra \\ ${ }^{4}$ Research Scholar Department of Management Sciences, Hazara University Mansehra \\ ${ }^{4}$ Lecturer, Department of Management Sciences, Hazara University Mansehra, \\ ${ }^{5}$ Deputy Director (ORIC) Hazara University Mansehra
}

\begin{abstract}
The thrust of the study lies in knowing the impact of job security on the employees' performance. In this study it is analyzed that private sector hospitals of Hazara Disivion higher management is continuously endeavor to improve Job security and trust because it is beneficial for improved employees' performance and private sector hospitals of Hazara Disivion productivity as well as effective implementation of strategic plans. In this study we investigate that Job security and trust gives a conducive environment to develop employees' performance and also develop organizational efficiency and effectiveness. In this study we analyzed that Job security plays a mediating role between trust and employees' performance. In this case study survey method was used. Through random sampling technique data from 153 employees were collected. To evaluate the concepts data was analyzed by using mediation test by the implementation of regression analysis. Hypothesis results indicated that job security has a partial mediation with trust and employees performance.

Lastly, Research discussion and conclusion, directions for the future research of the private sectors hospitals employees' were discussed in detail.
\end{abstract}

Keywords: Job security, trust, employees' performance,

\section{Introduction}

Recently most of the organizations are working for the improvement of the Job security in the organization for the better performance of the employees'. Without the human resource element it is believed that an organization can neither grow nor develop. Storey (2001) stated that, it is Human Resource Management that creates "the ability to attract and hold on to talented employees is the single most reliable predictor of overall Excellence" From this it can be seen that the selection, training and retention of employees is avital element for a successful organization.

Employees' turnover is best understood as the movement of Employees', out of and into a working organization, Argyle, M. (1989). The Job security can be explained as an important attribute of organizational climate professed by an employee based on employee's subjective assessment for the entire workplace environment where he/she performs his/her duties (Costigan, Berman, 1998). The need of the trust among the employees and its co-workers is essential because it affects the performance of the employees at workplace (Mayer, Davis and Schoorman, 1995; McAllister, 1995). (Lucky, Minai, \& Rahman,(2013) has explained in their study that job security is essential for the betterment of the employees' Performance.

Job insecurity affects attitude, behavior and health of employees (Sverke, Hellgren and Näswall, 2002). These two studies explain private sector organization owners, directors, executives should be aware to overcome these problems of the employees for the better and profitable results.(Jandaghi, Mokhles et al. 2011) also explains that job security also affect the job and organization commitment of an employees.

\section{Problem Identification}

The problem is that in the private sector hospitals the employees' trust on the organization decreasing from the last three years due absence of the job security in the organization. In these three years organization got severe losses on the behalf of downfall in the reputation on the organization at the nation. Within the organization the employees' turnover drastically increases due to absence of the job security. This type of job security risk was also identified in European countries in 1999 and 2007 in Bangladesh. The management and policy maker of these countries took some remarkable steps to mitigate the risk of downfall of the organization success. These countries insured employees' job security. 


\section{Literature Review}

A review of studies conducted by different researchers defines that in the private sector organizations employees' performance is dependent on the variable like Job security (Judge \& Hies, 2002).Employees' performance is important for improving the performance of private sectors hospitals of Pakistan.

Recently most of the organizations are working for the improvement of the trust in the organization for the better performance of the employees'. The trust concept becomes known in the late 1930s with the work of social scientists lewin and his colleagues (Lewin et.al., 1939).

The trust can be explained as an important attribute of organizational climate professed by an employee based on employee's subjective assessment for the entire workplace environment where he/she performs his/her duties (Costigan, Ilter, 1998). The need of the trust among the employees and its co-workers is essential because it affects the performance of the employees at workplace (Mayer, Davis \& Schoorman, 1995; McAllister, 1995). Trust is a main element which affects the performance of the employees at the workplace.

According to the definition, trust could be regarded as a special feature of organizational climate, reflecting a general and diffusive evaluation for trustworthiness of the environment in which employees perform their duties. This study has conducted in China in manufacturing and IT organization by LI Ning, YAN Jin in 2009.In Pakistan almost 70\% of the population goes to the private hospital instead of public hospital. Here the role of the employees on the job regarding trust is vital. If the employees feel secure themselves then they perform well.

\subsection{Employees' Performance}

Mwita (2000) defined that employees' performance can be major factor of multidimensional aspects those have the strategic and strong link to the objectives of the organization. Organization productivity and efficiency at the work place can be measure by the real performance of the employees (Cascio, 2006). Performance can also be explained that employees' in according to organization rules and policies are carrying out his/her job discretion, assignment or task. It defines that accomplishment of a work or task that employees complete on his job. It explains that employees that how to do a work in the organization setup and accomplish his task as according to the organization polices and procedure.

Employees' performance is related with the Job performance which can be defined as, the final productivity of the employees' which is achieved by modification in their skills and abilities (Jones, 2003; Porter, Stress, Mowday \& Boulin, 1974). Employees' performance is the individual (employee) identification and involvement to a particular task of the organization. Employees' performance is the name of employees' commitment with the organization Which is according to Poter at al. (1974) include a desire to work in the organization for long time; work enthusiastically from his/her own will and; have the belief for the acceptance of the goals and tasks of the organization.

The employees' performance can be defined as that is related to the effectiveness of the employees' against their task and assignment (Medly \& Shannon, 1994).

Hughes (2007) conducted surveyed of different industries at multiple level he explained that work place quality affect the employees' attitude and increases their productivity level.

In the contemporary world, competitive environment of the organization has become the most important factor both for private and public sector organizations. The scholars working on the public or private administration have highlighted the need for betterment pliability and competitiveness (Behn 1995; Pooja \& Renu, 2005). They also argued in their study that performance of the employees' can be achieved if they feel secure at the work place.

Employees' performance mainly depends on various aspects like performance appraisals, salary, employees trust, motivation, job satisfaction, compensation, training and development, organizational structure and coaching etc (Tzafrir, Harel, Baruch \& Dolan, 2004).Dyer and Holder (1988) described in their study that high level of training and coaching investment promotes employee performance in the organization. Thus training and coaching to employees indicates that the organizational management cares about them and wants to promote their skills and knowledge about their jobs. Training and coaching give employees a skill which affects the performance of the employees. Hence, employees' performance can be operationally defined as the typical level of output an individual (employee) delivers in a normal way to fulfill a role of his job. Performance shows the employees' productivity against their job description.

Employee performance can also be operationally defined as that it shapes and conditions the value of learning new skills for employee's perception at work place. If the perceptions of employees are positive, then the psychological state of the employees will be positive and as a result they will feel secure in an organization. Performance is also a function of individual differences such as an aptitude for the job task. Performance of the employees is related to their motivation at workplace.

In current era organization goals can't be achieved by the efforts of one or two individuals, but it needs combined attempt of all the member of the organization (Crampton \& Wagner, 1994).The better performance of 
the employees, the organization needs to build the employees' skill and knowledge(Moon, 2001). Therefore, nowadays employees are considered to be main actors and valuable capital of organizations.

Moreover, if the employees in an organization are having trust within and out of the organization, it would improve the capacity of the employees (Barney \&Wright, 1998). Within the organizational environment, if employees' feel lack of trust, this will bring organizational increase in costs, employees' absence from job, lack of commitment, refusal to show services against the job responsibilities, strikes and conflict, lack of interest, achievement and motivation level, decrease in inspiration and novelty, lack of internal collaboration, difficulties in achieving the organizational objectives, and ultimately a decrease in the productivity level of the employees(Cappelli 1997;Straka 1990).

\subsection{Trust}

The word trust is derived from the German word trost, which means comfort. How a trust build in the organization, among the different stakeholders different researchers have worked on the development and formation of the trust (Dirks \& Ferrin, 2001). How and why people trust among $\mathrm{n}$ each other. This concept remained questionable for the researchers for long period of time. A rich literature about trust points out that it is an important variable in intera-organizational and inter-organization cooperation. Trust play a significant role in satisfying the organization stakeholders either stakeholders' are patients, government employees' or any other organization members, supplier or consultant their role as a public trust is important which is also called as a inter-agency trust, which provide information on the performance of the different organizations system from a stakeholders, perspective \{Goudge, $2005 \# 19$ \} Thus trust either it is a public trust or inter-agency trust both have vital importance for the effectiveness and efficiency of the organization.

\subsection{Job Security}

Organizations are such type of social structural systems, in which human resources are the main actors and their importance is unavoidable. In the organization the effectiveness and efficiency can be achieved when effective management of the organization achieving its objectives. Job security has an importance for the organizational performance and its employees.

Herzberg (1968) make clarified that job security is a degree of satisfaction of an employee about his employment which an organization provide him. Job security can be further defined as that it is such type of security which is associated with increase in employment exit rate rather than decline in average tenure (Kugler, 2000).

Perry and Porter (1982) explained that to achieve the best outcomes of the employees, job security is necessary for the organization. They also explained that job security and competitive analysis has its own importance for employees' performance.

Ivancevich, Konopaske and Matteson (2005) stated that quality in employees' work and organization is related to the philosophy of the management conditions that motivate the employees' dignity and wellbeing physically and emotionally to bring changes in the organization culture and environment. They explained that quality of a job is a broader term but the satisfaction of the employees regarding their job is important. Several authors explained that organization needs a lot of work to bring the quality, productivity, effectiveness of the employees and organization by securing the employees' job security. Managers need to study the employees' needs and factors which satisfied them, secure their job and provide them trustworthy environment. Iverson (1996) defined that if greater the job security then greater will be the commitment of employees with the organization. Employees' satisfactions related to their job give them an attachment and commitment with their work.

Bassey (2002) make cleared that skill; task identity, task significance, autonomy, feedback, job security, and compensation are main motivational factors for the employees within the organization for the goal achievement. He defined that organizational goals can be achieved if the organization job design should be in favour of the employees. The role of job security is very important for satisfaction of the employees and their performance within the organization. Within the organization, positive perceptions of the employees about their working condition, will lead to greater perceived performance capacities.

The thing which block employees' productivity are insecurity of the job. Job insecurity is not only interrelated with the potential loss of employment but also creates, job uncertainty, lack of promotional opportunities and same level of job responsibilities for the employees careers (Greenhalgh \& Rosenblatt, 1984). The two research study indicates that insecurity and risk of the job make a condition of perceived powerlessness of employees to sustain their preferred continuity job in a vulnerable situation. This means job security is the sum of threats and stress, which affect the employees' performance at their job. Job insecurity has diverse and risky effects which not only affect the employees psychologically and economically but also affect organization goals and objectives (Smith, 1998). 
Caplan, Cobb, French, Van Harrison and Pinneau, (1975) presented in his study a different type of evidence that employees' perceptions about the job security changed with the passage of time. He used General Social Survey (GSS) from 1977-1996, he derived the results that with the change and loss of the job it became difficult for the employees' to find the suitable job.

Job security (Kanfer, Wanberg, \& Kantrowitz 2001) is a difficult idea to define or study in private sector organizations where multiple issues are coming across every day activities. Due to new environment and new structure of the organization it becomes difficult for the organization to create job security of the employees. The issues and problems arise in most of the private organization where most of the employees feel unsecure psychologically depressed and themselves. It means that job insecurity can affect the private sector organization performance.

Ashford (1989) explained in his study that the impact of job insecurity has a strong impact for the employees that effect the organizational work devotion and commitment, job satisfaction, and ultimately work performance. They also examined that job insecurity show the way to employees to reduce their commitment to the organization. It means that job security, employees' commitment with the organization and their performances have mutual relationship with one another.

According to (Baker \& Abou-Ismail, 1993) job security means that someone is satisfied with his job then he would be more devoted with his organization and in this way he will perform his job in a productive manner. Job security could also be explained as a psychologically strong commitment of employees with organization and their job performance at the workplace. Job security operationally can be defined as, that how an employee is satisfied with his current job. Organizational life is related to the interaction between the employees and with customers trust. This trust can be built by the human resource management practices within the organization.

Job security has a positive relationship to job performance of the employees' (Carmeli \& Freund, 2004; Chen \& Silverthorne, 2005; Diefendorff, 2006). Job insecurity creates the risk of unemployment for an employee which has usually pessimistic psychological results. Employee dedication and commitment will become low in rating when he feels insecurity of his job within the organization. If an employee is mentally not satisfied with his work, he will not perform well. His mental health for creative work will be decreased, because of the risk of job loss.

Bowditch and Buono (2005) explained that organization problem of administration and management is emerging from ancient Greek times and pre-industrial societies. These societies were not well aware about the organization management problems and it was difficult for them to develop and manage effectiveness and efficiency at the organization level and for its employees. There were lack of job security, motivation, job commitment, and safety behavior in the organization.

Job security is determined by job performance as well as by market conditions. Job insecurity increases feelings of pressure and stress on the employees, which has a negative impact on employees' performance.

The framework is based on the assumptions that Job security will always favour an organization success. As a consequence, the framework also assumes that employees' in the private sector private sector hospitals of Pakistan will feel positively and strongly about the organization to they belong and will voluntarily support it.

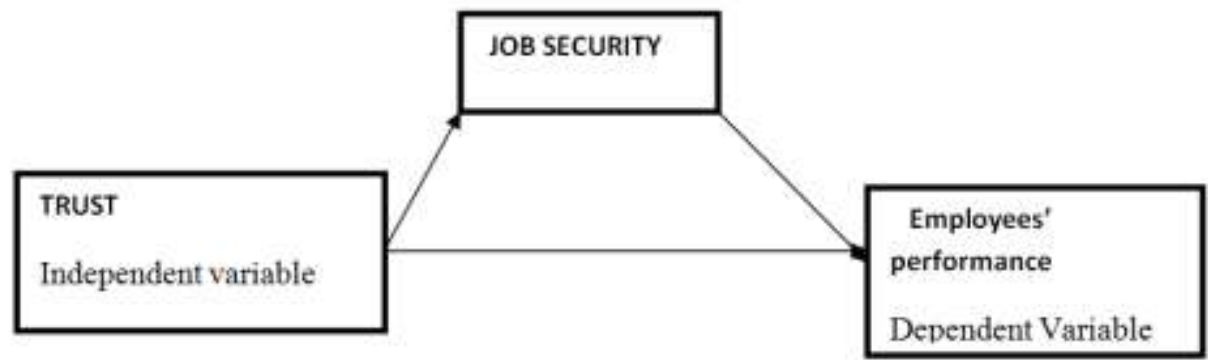

Figure.1 Model of trust, job security and employees' Performance

\section{Methodology}

Research methodology consisting of problem enunciating the problem, formulating of hypothesis, data collection of facts, data analyzing and researching on a conclusion from the analysis towards the solution of a concern problems in certain generalization fo some theoretical formulation (Kothari 2004).

\subsection{Psychometric Properties of the Scale}

Assessing validity of the scale is known as psychometric properties of the scale and the description of various types' validity analysis is provided as follows. 


\subsection{Validity Analysis}

Validity analysis is the ability of the scale to measure what it is intended to measure (Ellis and Levy 2010). For the current study different types of validity analysis such as face validity, content validity, criterion validity and construct validity were used. The face validity and content validity of the instrument were evaluated by giving the instrument to experts in the field. In order to enhance the face and content validity of the scale were sent to the experts in the field. Suggestions from the experts were incorporated in the scale before the final administration of the instrument. This was ultimately enhancing quality of the scale. Description of each type of validity is provided below.

\subsection{Face Validity}

For the current study (Nosek, Greenwald et al. 2005) was conducted in order to take insights whether the questionnaire provide accurate representation of the constructs it is measuring. This insight was taken from the management professionals, stakeholders of Hodpitals. On the judgment of these people highlights some discrepancies in the scale, the scale was revised and they were again be asked whether the revision is relevant or not.

\subsection{Content Validity}

Apart from assuring face validity of the scale content validity of the scale was generated by consulting with proposed respondents, experts in the field and review of associated literature. Leedy and Ormrod (2010) argued that in line with this an important strategy in generation of items is to revisit the research question in order to make sure that the items reflects research question and were relevant. This helped to ensure that items of the scale are representative of the construct.

\subsection{Criterion Validity}

A third type of validity analysis such as criterion validity was conducted for the study in hand. Criterion validity is the ability of a measure to correlate with other measures of the same construct (Rubin \& Babbie, 2012). Criterion validity is classified into concurrent validity and predictive validity. As in the current study there are no similar variables therefore only concurrent validity analysis was conducted.

\subsection{Reliability Analysis}

Along with different types of validity analysis for the current study reliability analysis was also be conducted in order to check the consistency of the measure. .80 is commonly considered as the threshold value and is represented by alpha. This was confirming the reliability of the instrument. The reliability analysis was conducted by using SPSS.

Questionnaires were designed as a tool for the collection of the data, 153 filled questionnaires were received from the employees. A simple random sampling technique was used to collect the data from the respondents. Mediation test was applied to analyze the data.

V.

\section{sults Analysis}

On the basis of narrative analysis technique these are the results. Different responses of the employees' of private sector hospitals came which included in detail in this part. It has been confirmed in the light of this research that Job security development within the organization can lead an organization towards a success. After conducting the whole research we can generate following conclusions in the light of the responses given by the respondents of this research.

\section{Step.1}

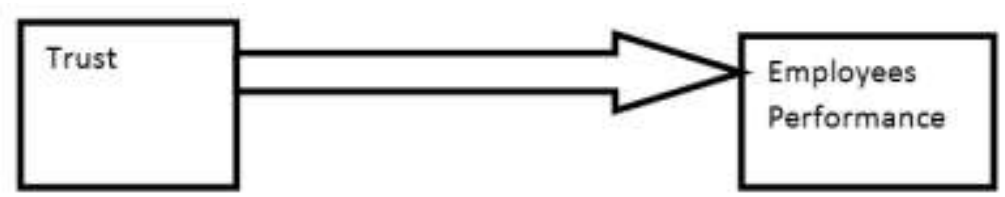

Figure 1.2: Relationship between Trust and Employees' Performance

Table 1.1: Coefficients

\begin{tabular}{|l|l|l|l|l|}
\hline Model & Unstandardized Coefficents & Standardized Coefficients & Sig. \\
\hline \multirow{3}{*}{ Constant } & $\mathrm{B}$ & Std Error & Beta & \multirow{2}{*}{.981} \\
\cline { 2 - 4 } & .001 & .042 & .483 & .43 \\
\hline
\end{tabular}


A Mediating Role of Job Security between Trust And Employees' Performance: A Case of Private....

\begin{tabular}{|l|l|l|l|l|}
\hline Trust & .503 & .043 & & .000 \\
\hline
\end{tabular}

Table 1.1 explains that there is a positive and significant relationship between trust and employees performance. Step. 2

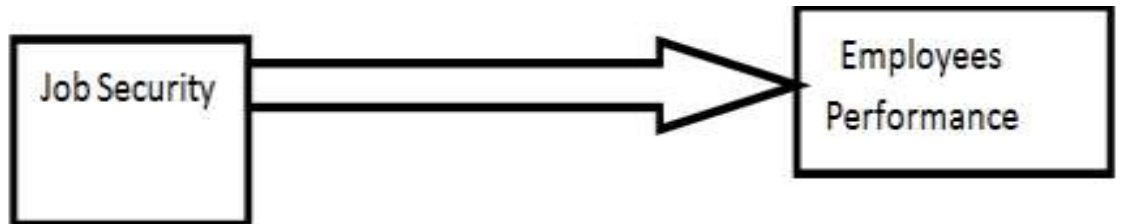

Figure.1.3: Relationship between job security and employees Performance

Table 1.2: Coefficients

\begin{tabular}{|l|l|l|l|l|}
\hline Model & \multicolumn{2}{|l|}{ Unstandardized Coefficient } & Standardized Coefficient & Sig. \\
\hline Constant & B & Std Error & Beta & \\
\cline { 2 - 5 } Trust & .001 & .044 & .207 & .989 \\
& .205 & .048 & & .000 \\
\hline
\end{tabular}

From the step 2 interpretation it is clear that when mediating variables is taken as a dependent variable then relationship between trust and job security also remained positive and significant.

Step 3

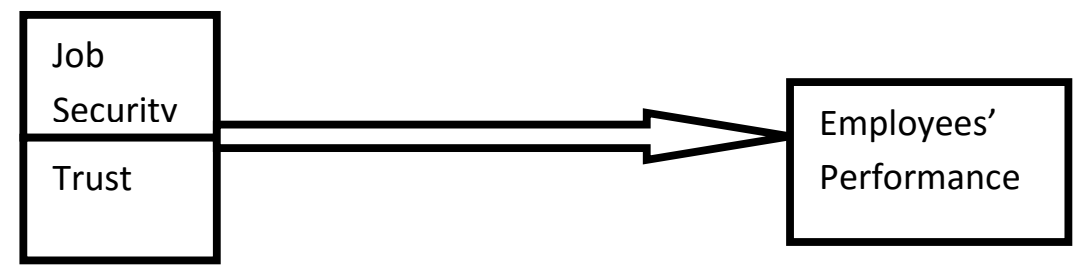

Figure: 1.4: Relationship between Job security, trust and Employees’ Performance

Table 1.3: Coefficients

\begin{tabular}{|c|c|c|c|c|}
\hline & \multicolumn{2}{|c|}{ Unstandardized Coefficients } & Standardized Coefficient & Sig. \\
\hline \multirow{4}{*}{$\begin{array}{l}\text { Constant } \\
\text { Trust } \\
\text { Job Security }\end{array}$} & $\mathbf{B}$ & Std Error & Beta & \\
\hline & .001 & .041 & & .983 \\
\hline & .483 & .047 & .474 & .000 \\
\hline & .105 & .045 & .102 & .023 \\
\hline
\end{tabular}

Table 1.3 also explains job security and trust as a significant relationship but as a whole trust significance level reduced that shows that job security has partial mediation with trust and employees performance.

Table.1.4: Cumulative Table of Coefficients

\begin{tabular}{|l|l|l|l|l|}
\hline Steps & Path & Beta (unstandardized & Standard error & Beta Standardized \\
\hline Step 1 & C & .503 & .042 & .483 \\
\hline Step 2 & $d$ & .204 & .041 & .207 \\
\hline Step3 & $b$ & .105 & .045 & .102 \\
\hline Step 4 & $c$ & .482 & .046 & .473 \\
\hline
\end{tabular}

Table 1.4 clarify overall three steps interpretation in a sequence and meaningful manner.

Productivity of an organization depends on the skills or expertise of its workforce. A skilled worker may be an asset for any organization. If a skilled person leaves an organization the effects will be very high where as in case of a semiskilled or un-skilled person the effect will be less. As a result, a vacant place of a skill labor may be filled by another new worker but organization performance falls due to their skill difference In this study generally data was highly correlated for the variables under investigation (Job security and employees' performance).Most of the administrative officers viewed that Job security is a necessary factor for the performance of the employees and also it is important to increase the satisfaction level of the employees with the services of the private sector hospitals employees'. For the data analysis it was cleared that more intension to leave the organization is due to the factor of salary problem within the organization.

This study also satisfied the recommendations of the Naresh and Pawan work (1999) which is conducted in an industrial sector. 


\subsection{Directions for the Future Study}

This research case study suggested that unfavorable environment affect the employees' performance directly and supportive environments have the significance and positive effect on the employees' performance and its productivity level. Here authorities need to understand the trust as well as Job security importance for the better results of the organization development.

Most of the work of this paper is obviously theoretical but a complete mathematical model to measure this turnover rate can be done in future research case study. If the skill of the employee or worker is expressed in terms of weight or in percentage, a mathematical model then could be possible to measure the direct relationships of turnover and employees' performance. To develop such model we have to consider so many factors such as; relationships among wage and salary structure, compensations, fringe benefits, location advantage, job security, social and economic factors to turnover etc. To integrate all these factors in a model could show a new way to control turnover for the managerial concern. It means that job security and employees' performance have the ideal phenomena for the study for the future research. Organization should realize the need of trust need to build a long term strategic goal of the organization. Private hospitals top management need to revise polices regarding job security to enhance the productivity level of the employees'. For the generalization of the result the data can be tested for the many other case studies for testing the theoretical model. In this research color index technique of goal theory of motivation can also be used.

\subsection{Directions for Private Sector Hospitals Owners and Employees'}

In the views of the respondents it is concluded that an overall turnover rates within studied organization can be reduced if proper steps should be taken for the improvement of the employees' job security. Organization should take measurable steps to minimize the threat of employees' leaving the organization because of the factors which are not going in their favor. Top management and policy makers of the organization should make policy to tackle this situation. Organization should revise its strategies of salary, working environment, health insurance etc for the better performance of the employees' and organization.

VI.

\section{nclusion}

This study gave us the ample proof that if the job security issues remain in the private sector hospitals of Pakistan, then the employee's performance also suffer in this regards. This study also explains the result of (Lucky, Minai, \& Rahman, 2013; Sverke, Hellgren\& Näswall, 2002) work which was conducted in multiethnic environment. It means that private sector owners should ensure the job security of the employees for the productive work. It is cleared that job security mediating role has a significance in the building of trust among the employees of the private sector hospitals of Pakistan.

\section{References}

[1] Argyle, M., (1989), The Social Psychology of Work, Penguin London Ashford, S.J., Lee, C. \& Bobko, P. (1989).Content, causes and consequences of job insecurity: a theory-based measure and substantive test, Academy of Management Journal,32(4),803-29.

[2] Baker, M.J. and Fouad A-I (1993).Organizational buying behavior in the Gulf, InternationalMarketing Review, 10(6), 42-60.

[3] Bassey, M. (2002).Motivation and work: investigation and analysis of motivational factors at work, Retrieved from: www.ep.liu.se/exjobb/eki/2012/fek/009/

[4] Behn, D. (1995). The big questions of public management. Public Administration Review, 55, 313-324

[5] Bowditch, J.L., \& Buono, A. F. (2005).A primer on organizational behavior, 6th Ed. New York: John Wiley.

[6] Barney, J.B., \& Wright, P.M. (1998). On becoming a strategic partner: the role of human resources in gaining competitive advantage, Human Resource Management, 37, 31-46.

[7] Caplan, R.D., Cobb, R.S., French, J.R.P. Jr, Van Harrison, R.V. \& Pinneau, S.R. Jr (1975), Job Demands and Worker Health: Main Effects and Occupational Differences, US Department of Health, Education, and Welfare, Washington, DC.

[8] Carmeli, A., \& Freund, A. (2004).Work commitment, job satisfaction and job performance: an empirical investigation, International Journal of Organization Theory and Behaviour, 7 (3), 289-309.

[9] Cascio, W. F. (2006). Managing Human Resources: Productivity, Quality of Life, Profits.

[10] McGraw-Hill Irwin. Chen, J.C., and Silverthorne, C. (2005).Leadership effectiveness, leadership style and

[11] employee readiness. Leadership \& Organization Development Journal, 26 (4), 280-88.

[12] Crampton, S. M., \& Wagner, J. A. (1994). Percept-percept inflation in micro organizational research: An investigation of prevalence and effect. Journal ofApplied Psychology, 79, 67-76.

[13] Diefendorff, J.M., Richard, E.M. \& Gosserand, R.H. (2006).Examination of situational and attitudinal moderators of the hesitation and performance relation, Personnel Psychology, 59(2), 365-93.

[14] Dirks, K. T., \& Ferrin, D. L. (2001). The role of trust in organizational settings. Organization

[15] science, 12(4), 450-467.

[16] Ellis, T. J. and Y. Levy (2010). A guide for novice researchers: Design and development research methods. Proceedings of Informing Science \& IT Education Conference, InSITE, Citeseer.

[17] Greenhalgh, L., \& Rosenblatt, Z. (1984).Job insecurity: toward conceptual clarity. Academy of Management Review, 9(3), 438-48.

[18] Goudge, J., \& Gilson, L. (2005). How can trust be investigated? Drawing lessons from past experience. Social science \& medicine, 61(7), 1439-1451.

[19] Herzberg, F. (1968).Work and the nature of man.London:Granada. 
[20] Huges, J. (2007, July). Office design is pivotal to employee productivity. Sandiego source the daily Transcript.

[21] Ivancevich,J.M.M., Konopaske, R., \& Matteson, M.T.( 2005). Organizational Behavoiur and anagement.(7 ${ }^{\text {th }}$ ed) MCGrawHill/Irwan New York.

[22] Iverson, R.D. (1996). Employee acceptance of organizational change: the role of organizational commitment. The International Journal of Human Resource Management, 7(1), 122-49.

[23] Jandaghi, G., et al. (2011). "The impact of job security on employees' commitment and job satisfaction in Qom municipalities." African Journal of Business Management 5(16): 6853.

[24] Jandaghi, G., et al. (2011). "The impact of job security on employees' commitment and job satisfaction in Qom municipalities." African Journal of Business Management 5(16): 6853.

[25] Jones, G. R. (2003) .Organizational Theory, Design, and Change, Upper Saddle River: Prentice Hall.

[26] Judge, T. A., \& D. M. Cable. 1997. Applicant Personality, Organizational Culture, and Organization Attraction. Personnel Psychology 50: 359-394. And R. Lilies. 2002"Relationship of Personality to Performance Motivation: A Meta-analytic Review. Journal of Applied Psychology 87 (4), 797-807.

[27] Kanfer, R., Wanberg, C. R., \& Kantrowitz, T. M. (2001). Job serch and employment: a Personality-motivational analysis and metaanalytic review. Journal of Applied Psychology, 86(5), 837-855.

[28] Kothari, C. R. (2004). Research methodology: Methods and techniques, New Age International.

[29] Kugler, A. (2000).The Incidence of Job Security Regulations on LaborMarket Flexibility and Compliance in Colombia: Evidence from the 1990Reform.Research Network Working Paper R-393. Washington: InterAmerican Development Bank (IDB).

[30] Lewin, k., lippih R., \& White, R. K. (1939). pattern of aggressive behavior in experimentally Created social climate, journal of social psychology, 10(2), 271-299.

[31] Lucky, E. O. I., Minai, M. S., \& Rahman, H. A. (2013). Impact of job security on the organizational performance in a multiethnic environment. Research Journal of Business Management, 7(1), 64-70.

[32] Moon, H. (2001).The Two Faces of Conscientiousness: Duty and Achievement striving in Escalation of Commitment Dilemmas. Journal of Applied Psychology86 (3), 533- 540.

[33] Mwita, J. I. (2000).Performance management model: A system-based approach to system quality. The International Journal of Public Sector Management, 13(1), 19-37.

[34] Nosek, B. A., et al. (2005). "Understanding and using the Implicit Association Test: II. Method variables and construct validity." Personality and Social Psychology Bulletin 31(2): 166-180.

[35] Perry, J. L., \& Porter, L., W. (1982). Factors affecting the context for motivation in public organizations. Academy of Management Review, 7(1), 89-95

[36] Pooja G., \& Renu, R. (2005, September 7).New model of job design: motivating Employees 'performance Department of Humanities and Social Sciences, Indian Institute of Technology Roorkee, Roorkee, Uttaranchal, India.

[37] Porter, L.W., Stress, R.M., Mowday, R.T., \&Boulin, P.V. (1974). Organization commitment, and turnover among psychiatric techniques, journal of Applied psychology, job satisfaction 59,603-609.

[38] Rootes. C. (ed.) (1999), Environmental Movements. Local, National and Global, (London: Frank Cass)

[39] Storey. J., (2001), Human Resource Management: A Critical Text, 2 nd. Edition Thomson Learning.

[40] Sverke, M., Hellgren, J., \& Näswall, K. (2002). No security: a meta-analysis and review of job insecurity and its consequences. Journal of occupational health psychology, 7(3), 242.

[41] Tzafrir, S.S., Harel, G.H., Baruch, Y., \& Dolan, S.L. (2004). The consequences of emerging HRM practices for employees' trust in their managers, Personnel Review, 33, 628-47.

[42] Whitener, E.M. (2001). DO high commitment human resource practices affect employee commitment? A cross-level analysis using hierarchical linear modeling. Journal of Management, 25(5), 515-535.

\section{Annexure}

\section{Annex 'A'}

\section{QUESTIONAIRE FOR EMPLOYEES OF THE HOSPITALS}

A Mediating role of job security between trust and employees' performance: A case of Private Sector Hospitals of Hazara Division, Pakistan

My name is Waqar Ahmad; I am the student of PhD in Hazara University Mansehra. I and other authors Dr. Muhammad yasir, Imran and Rashed and Akhtar Nawaz want to collect the data for the purpose of my research work on the topic "A Mediating role of job security between trust and employees' performance: A case of Private Sector Hospitals of Hazara Division, Pakistan"

". The respondent's data will be kept confidential.

Name of the Hospital Date of establishment

Respondent's Gender___ Monthly Income (optional) to $60 / 60$ above) Qualification

Designation of the respondent

Date of filling the questionnaire

Scale $1=$ strongly Disagree $2=$ Disagree $\quad 3=$ moderately agreed $4=$ Agreed

$5=$ strongly agree

Please read the following statements carefully and tick $(\sqrt{ })$ that best describe your opinion. The criteria for ticking the statements are given at the end of each statement

\section{Job security}

JS1. Organization rules and regulations support the employees' future in the form of job.

\begin{tabular}{|l|l|l|l|l|}
\hline $\mathbf{1}$ & $\mathbf{2}$ & $\mathbf{3}$ & $\mathbf{4}$ & $\mathbf{5}$ \\
\hline
\end{tabular}


JS2. I am satisfied with the present job or business in term of job security.

\begin{tabular}{|l|l|l|l|l|}
\hline $\mathbf{1}$ & $\mathbf{2}$ & $\mathbf{3}$ & $\mathbf{4}$ & $\mathbf{5}$ \\
\hline
\end{tabular}

JS3. The top management of this organization defined and explained his strategies regarding employees' job security that we should enjoy our work for better services for the customers.

\begin{tabular}{|l|l|l|l|l|}
\hline $\mathbf{1}$ & $\mathbf{2}$ & $\mathbf{3}$ & $\mathbf{4}$ & $\mathbf{5}$ \\
\hline
\end{tabular}

JS4. I am satisfied with the personal relationship with the employees', job security and professional support by the management of the organization.

\begin{tabular}{|l|l|l|l|l|}
\hline 1 & 2 & 3 & 4 & 5 \\
\hline
\end{tabular}

JS5. Good working relation exist between you and your boss

\begin{tabular}{|l|l|l|l|l|}
\hline $\mathbf{1}$ & $\mathbf{2}$ & $\mathbf{3}$ & $\mathbf{4}$ & $\mathbf{5}$ \\
\hline
\end{tabular}

\section{Trust}

T1.Employees have clear understanding of common goals.

T2. There are gossips among the employees of the organization

\begin{tabular}{|l|l|l|l|l|}
\hline $\mathbf{1}$ & $\mathbf{2}$ & $\mathbf{3}$ & $\mathbf{4}$ & $\mathbf{5}$ \\
\hline
\end{tabular}

T3. The organization deals with issues of trust among employees and other people involved.

\begin{tabular}{|l|l|l|l|l|}
\hline $\mathbf{1}$ & $\mathbf{2}$ & $\mathbf{3}$ & $\mathbf{4}$ & $\mathbf{5}$ \\
\hline
\end{tabular}

T4. Level of employee's trust is very important in our organization.

\begin{tabular}{|l|l|l|l|l|}
\hline $\mathbf{1}$ & $\mathbf{2}$ & $\mathbf{3}$ & $\mathbf{4}$ & $\mathbf{5}$ \\
\hline
\end{tabular}

T5. Our organization tries to empower people to take part in decision making.

\begin{tabular}{|l|l|l|l|l|}
\hline $\mathbf{1}$ & $\mathbf{2}$ & $\mathbf{3}$ & $\mathbf{4}$ & $\mathbf{5}$ \\
\hline
\end{tabular}

T.6. All the employees are moving together in same direction.

\begin{tabular}{|l|l|l|l|l|}
\hline $\mathbf{1}$ & $\mathbf{2}$ & $\mathbf{3}$ & $\mathbf{4}$ & $\mathbf{5}$ \\
\hline
\end{tabular}

T7. Employees in our organization have understanding of what is expected of them.

\begin{tabular}{|l|l|l|l|l|}
\hline $\mathbf{1}$ & $\mathbf{2}$ & $\mathbf{3}$ & $\mathbf{4}$ & $\mathbf{5}$ \\
\hline
\end{tabular}

T8. Employees do not have any complaints about co workers.

\begin{tabular}{|l|l|l|l|l|}
\hline $\mathbf{1}$ & $\mathbf{2}$ & $\mathbf{3}$ & $\mathbf{4}$ & $\mathbf{5}$ \\
\hline
\end{tabular}

\section{Employees' Performance}

Ep1. Respect, trust and support from the employees' affect the employees' productivity level in the form of performance.

\begin{tabular}{|l|l|l|l|l|}
\hline 1 & 2 & 3 & 4 & 5 \\
\hline
\end{tabular}

EP2. I am willing to put extra effort when necessary to complete the assigned job.

\begin{tabular}{|l|l|l|l|l|}
\hline $\mathbf{1}$ & $\mathbf{2}$ & $\mathbf{3}$ & $\mathbf{4}$ & $\mathbf{5}$ \\
\hline
\end{tabular}

EP3. I receive positive feedback and to be improved in regarding my job description.

\begin{tabular}{|l|l|l|l|l|}
\hline $\mathbf{1}$ & $\mathbf{2}$ & $\mathbf{3}$ & $\mathbf{4}$ & $\mathbf{5}$ \\
\hline
\end{tabular}

EP4.My organization acknowledges me for my contribution when organizations goals and objectives are achieved.

\begin{tabular}{|l|l|l|l|l|}
\hline 1 & 2 & 3 & 4 & 5 \\
\hline
\end{tabular}

EP5. The staff development programe helped me to add value to my skills and knowledge.

\begin{tabular}{|l|l|l|l|l|}
\hline $\mathbf{1}$ & $\mathbf{2}$ & $\mathbf{3}$ & $\mathbf{4}$ & $\mathbf{5}$ \\
\hline
\end{tabular}

